\title{
TEMPELWACHTERS TE PRAMBANAN?
}

Naar aanleiding van mijn stukje over het bezoek van Reimer aan eenige tempelruïnen van Midden-Java in 1791, opgenomen in de vorige aflevering, vestigde Dr. R. D. M. Verbeek mijne aandacht op de reis van den onderkoopman en fiscaal van Samarang C. A. Lons, die de tempelruïnen nabij Prambanan in 1733 bezocht, van welke reis Dr. Leemans melding makte in zijn opstel "Javaansche tempels bij Prambanan" in de "Bijdragen" van 1855. (p. 1-26).

Ik dank den heer Verbeek voor zijne opmerking.

De onderkoopman Lons, die de aangetroffen beelden in de Prambanangroep vrij nauwkeurig beschreef, maakt ook melding van $" 8$ seer groote beelden, yder uyt een enkelde swaare steen "gehouden, leggende twee en twee verdeelt op byzondere plaatsen "tegens den anderen over, d'eene op deszelfs regter en die tegens "hem over op syu linkerknie, houdende in de regter hand een "knots, in de andere een slang om hun lighaam gekronkeld"; waarmede stellig tempelwachters bedoeld worden.

Het is echter niet geheel duidelijk, uit hetgeen Dr. Leemans nit Lons' handschrift mededeelde of die "8 seer groote beelden" tot de Prambanangroep behoorden of elders bijv. bij de Tjandi Sewoegroep werden aangetroffen.

Lons, na van den grooten Prambanan tempei verhaald te hebben en na gezegd te hebben dat de "overige groote capellen" door "ruygte" als anderszins ongenaakbaar waren, laat dan volgen : "Nog bezagen wij diverse capelletjes zonder onderscheyd van gedaante, fatsoen en groote als hetgeen dat op Salatiga gevonden wert" ; waarop dan volgt "ook 8 seer groote beelden enz."

Uit dat "Nog bezagen wij enz." zou af te leiden zijn dat hij daarmede een andere groep bedoelde, wat dan de Tjandi Sewoe groep zou kunnen zijn; in welk geval de tempelwachters door Lons beschreven dan niet tot de Prambanangroep behoord zouden hebben.

Het is wel jammer dat Lons en Reimer beide ons min of meer 
in het onzekere laten omtrent de bezochte plaatsen; al is 't ook zeker dat Lons den hoofdtempel van de Prambanangroep bezocht, de mogelijkheid is niet uitgesloten dat hij zijn bezoek nog verder uitstrekte.

Toch meen ik op de groote waarschijnlijkheid te mogen wijzen dat ook die laatste groep hare tempelwachters heeft gehad; uit beider mededeelingen $\mathrm{k}$ a $\mathrm{n}$ dit worden afgeleid.

H. D. H. B. 